\title{
DEVELOPMENT OF A REGION-CENTRIC WEBSITE TO SUPPORT DATA TRACKING OF COVID-19 PATIENTS IN KELURAHAN GUNUNG
}

\author{
Linus NG ${ }^{1}$, Samuel Mahatmaputra TEDJOJUWONO² \\ ${ }^{1}$ Business Information Systems, Information Systems Department, Faculty of Computing and Media, Bina \\ Nusantara University, Jakarta, Indonesia, 11480 \\ ${ }^{2}$ Computer Science Department, Faculty of Computing and Media, Bina Nusantara University, Jakarta, Indonesia 11480, \\ e-mail: smahatmaputra@binus.edu
}

\begin{abstract}
The deadly Coronavirus, SARS-COV-2, which is known as COVID-19 has caused global panic as it has affected multiple countries and millions of people around the world. Despite the existence of vaccines, every country in the world is trying their best to limit the spread of the virus. However, as the active cases starts multiplying each day, keeping track of the data of each person living in the world is becoming a much difficult task. The management of the subdistrict "Gunung" in Jakarta, Indonesia had mentioned that there is a lack of automated systems to maintain data. Therefore, with Information Systems and the technology we have nowadays, we are able to develop something that could aid us in keeping accurate and detailed information of the patients and unaffected citizens. Using PHP, HTML, JavaScript and MySQL, a website was developed to keep track of the citizen of Kelurahan Gunung, while also keeping track of the swab test results. The aim of proposed solution to the problem can be described as to present additional information support regarding the pandemic for population data and to present an information system for government and residents in Kel. Gunung regarding the assistance services available during the pandemic.
\end{abstract}

Keywords: COVID-19, Coronavirus, SARS-COV-2, Website, PHP language, Kelurahan Gunung.

\section{INTRODUCTION}

The Coronavirus, SARS-CoV-2, also known as COVID-19 has been classified as a worldwide global pandemic by the World Health Organization (WHO) on March 11, 2020, and as of July 16, 2021, the total COVID-19 cases globally is sitting at $189,785,422$. In Indonesia, the total case is sitting at 2,726,803 and on July 16,2021 , Indonesia peaked at 56,757 cases confirmed in a day. Tracking each one of citizen's data, the places they have visited, and their vaccine and/or COVID-19 infection status is extremely important to pinpoint the affected areas. Therefore, utilizing Information Systems, we can develop a way to keep track of each citizen to identify which area should be avoided and keep track of which household is affected greatly by the virus. The system will keep track of a citizen's data, their Family ID, to keep track of relatives in case they get affected, and the swab test results that updates their COVID-19 status on every data entry. As of now, a few districts in Indonesia do not have a system like that. In addition, the government overseeing the Gunung subdistrict has requested Bina Nusantara University to develop a system and website specifically for their subdistrict to maintain the data efficiently. Therefore, on this paper, there is an assumption that the website is focused on Kelurahan Gunung, which is a subdivision of a district in Jakarta, Indonesia. The cases of Gunung subdivision alone sits at 209 total active cases. The website will contain information and material for the general public to inform themselves. This includes debunking hoaxes, the hospital within the districts, emergency numbers, and basic health protocols to fight against the Coronavirus. However, government officials and medical staff would be able to log into the back end of the website to access the data of each citizen in the subdistrict, with the ability to create, edit, and delete these data. In addition, medical staff would also be able to input swab test data that would automatically update the citizen's COVID-19 status, keeping track of whoever is positive.

\section{METHOD}

The proposed work aims at providing Kelurahan Gunung with an integrated information systems that could be accessed through the Internet. The output of this proposal is an integrated information system with software support to carry out epidemiological surveillance related to COVID-19. This application allows registration of all those tested for the SARS-CoV-2 virus in the Kelurahan Gunung area. Beneficiaries of this application are health service institutions at the kelurahan level, public health institutions, sanitation supervisors, government Kel. Gunung, as well as people in related areas. The proposed implementation method is as follows:

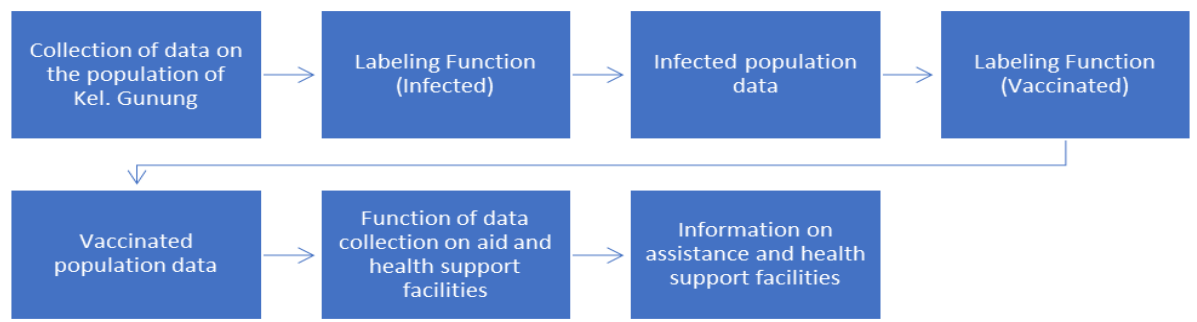

Picture 1. The proposed methodology 
This allows the collection of data from official records kept by the local government and related health institutions for residents of Kel. Gunung suffering from COVID-19 disease, public health institutions, as well as laboratories conducting tests, which enter data into the system. Data is stored at level one or local government using the cloud, which is in accordance with the area of public health institutions and institutions in Kel. Gunung. Those who have been vaccinated will also have their data collected either through data acquisition methods or through data entry by health workers.

\section{RESULTS AND DISCUSSION}

Responding to the threats and risks posed by COVID-19, this proposal adopts detailed population data in the Kel. Gunung that already exists to combat the COVID-19 pandemic by identifying data on the infected population, the population has been vaccinated and the availability of assistance and health services to support residents in the related kelurahan area. The proposed solution to the problem can be described as follows:

1. Presenting additional information support regarding the pandemic for population data in Kel. Gunung.

2. Presenting an information system for government and residents in Kel. Gunung regarding the assistance services available during the pandemic.

The following is detail of our partner: Kelurahan Gunung, Kebayoran Baru, Jakarta Selatan, Jl. Bujana Dalam No.7, RT.10/RW.5, Gunung, Kec. Kby. Baru, Kota Jakarta Selatan, Daerah Khusus Ibukota Jakarta 12120.

Through this solution, it is hoped that a coordinated movement will be created with the help of an information system between the Kel. Gunung's Government and its 11,000 residents to break the chain of spreading the virus. The following are some of the questions that have been designated to Kelurahan Gunung:

- What are the basic needs to realize an integrated information system in Kelurahan Gunung?

- What is the data collection and information system supporting the COVID-19 monitoring and vaccination process in Kel. Gunung has been digitized?

- Who are the stakeholders involved in the COVID-19 transmission and vaccination monitoring system in Kelurahan Gunung?

- What information is needed to support the process of monitoring, providing assistance and vaccination?

- If a web-based system is available to support the above process, can it be combined with the current systems?

\section{RELATED WORKS}

Some of the recent work conducted by Shrotri et al. showed the need of having a tracker application for an up to date yet comprehensive vaccine mapping across the monitored region plays important role in battling the global pandemic (Shrotri, 2021). One of the more advance work used predictive analysis presented by Hamzah et al. recently by developing an algorithm named SEIR (Susceptible-Exposed-Infectious-Recovered) predictive modelling. The algorithm could predict the outbreak of COVID-19 virus within certain region based on their past data (Hamzah, 2020). Some other more straightforward method to display predictive data used by Chandee et al. used a binomial statistical probability which could be developed rapidly and implemented immediately (Chandee, 2020).

Both predictive and descriptive data would be needed within those works to quickly and precisely tackle the outbreak before it could spread uncontrollably to the neighboring regions. The proposed system implemented for Kelurahan Gunung would -at this stage- use the descriptive approach to monitor COVID-19 outbreak among citizens and monitor the vaccination process to battle the global pandemic in the region.

\section{PROPOSED SYSTEM}

The proposed work would promote and support real time data input and retrieval to support Kelurahan Gunung monitors the outbreak within the region. The system uses Internet technology in a form website that is available to all the stakeholders including the medical officers. The website is written mainly in PHP language, and utilize HTML, JavaScript and CSS. In addition, Bootstrap is also used to make sure the website is compatible in most devices, and jQuery to assist with the data entry segment. The component of the website is also utilizing the Model-View-Controller (MVC) framework for scalable and extensive purposes, in a likely event where the government officials would want to add additional features in the future. Furthermore, the data are all stored inside a MySQL database that are currently local but will be converted into cloud when implemented. The website as of now is currently on its prototype stage, therefore, no UI design has been implemented and solely focus on the functionality.

\section{Front Page}

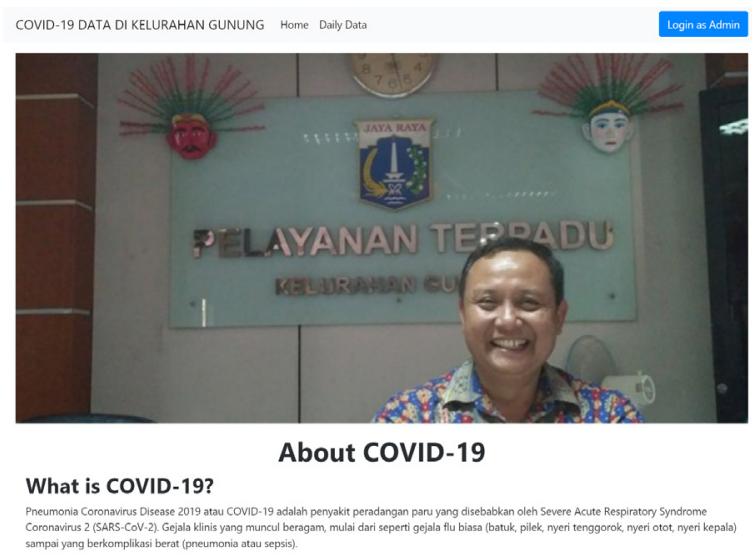

How does COVID-19 spread?

Picture 2. Front/Homepage 
The front page is visible to the general public that visits the website. It contains helpful informative details of the COVID-19 virus, ranging from the basic information of the virus itself, to the general health protocol and details to lower the risk of getting infected. In addition, there is also a list of hospital that is accessible around Kelurahan Gunung, and the numbers to call in case of an emergency. On the top, there is a tab that allows the user to access Daily Data too, to check the details of the COVID-19 cases as of today. In the future versions of the website, there will be additional tabs to add.

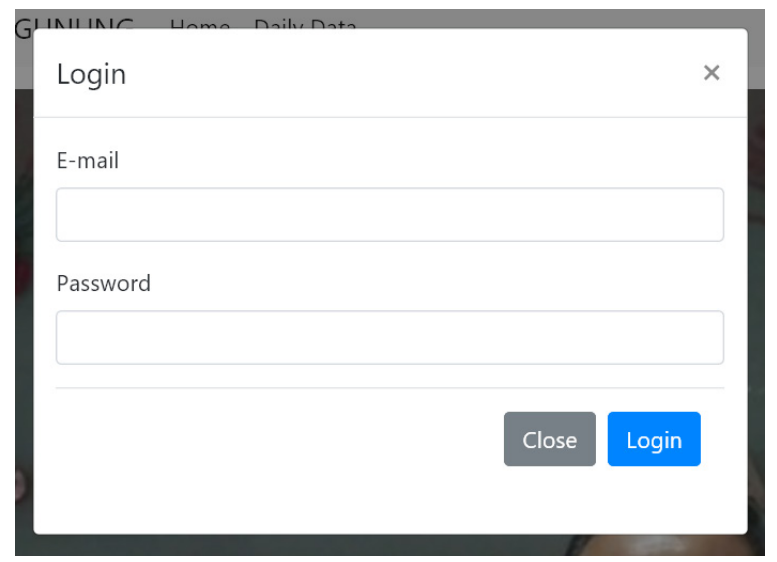

Picture 1. Log-in form that pops up when clicking "Login as Admin"

When clicking the "Login as Admin" button on the top right, the user will be greeted with a pop-up form that requires the user to input e-mail and password. This is strictly for government officials and medical staff that has an account to access. The general public are unable to access this, and there is no way to register since new admin users must be added directly from the database for safety purposes. The inputted email and password will be compared with the login details in the database and if it does not match, the user will be sent an error. When they enter a matching login credentials, they will be able to access the Admin page.

\section{Admin Page}
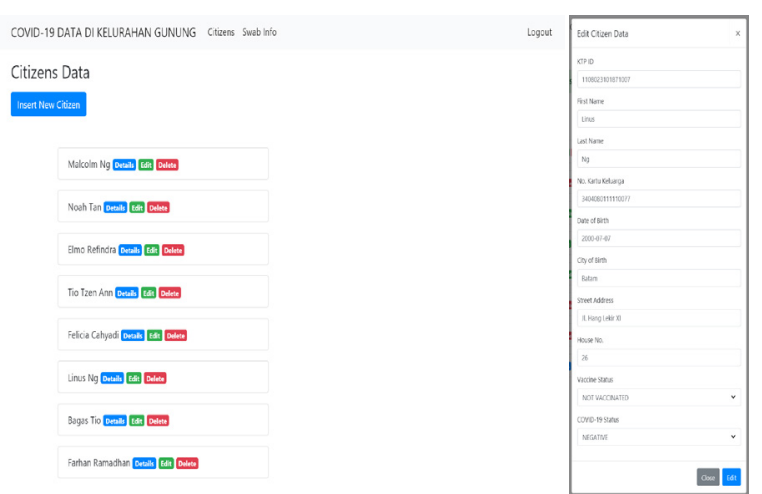

Picture 3. Citizens Data Page and Add/Edit Citizen Data form

After successfully logging in, the admin will have access to the Citizens and Swab Test Info tab. In the Citizen tab, it will show a list of citizens in Kelurahan Gunung. The user will only be able to see the citizen's name and other details are hidden within the "Details" button for privacy purposes. The detail includes: firstName, lastName, noKK (Family ID), dateOfBirth, cityOfBirth, streetAddress, houseNumber, vaccineStatus and covidStatus.

The admin will also be able to Insert New Citizens for anyone that recently moved in, and edit the existing data, or delete them. Using JavaScript, adding and editing citizens data roots from the same Modal form. When click the "Edit" button, the JavaScript code will immediately grab data based on the KTP ID and input in the empty field, for ease of usage.
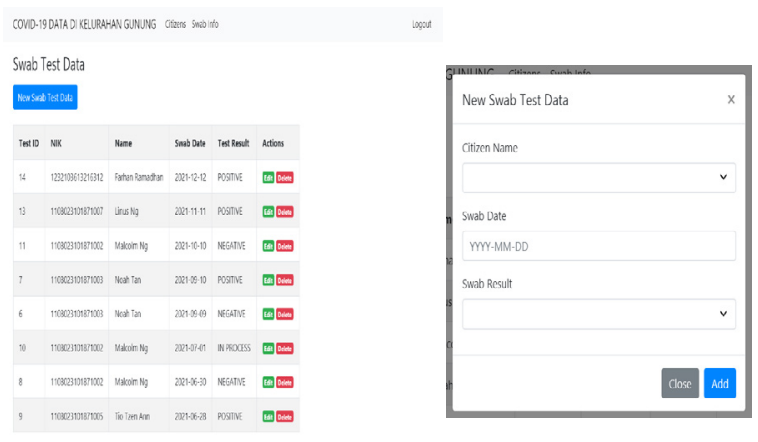

Picture 4. Swab Test Page and Add/Edit Swab Test Data form

The Swab Test page will be shown when clicking "Swab Info" on the top bar. In here, there is a table that list out all the swab test details, with the latest result sitting at the top based on date. For clarity purposes, all the details of the swab test are available immediately without having to click Details. The admin can click the "New Swab Test Data" button and input their own data. The Citizen Name will be taken directly from the Citizens Table, meaning that they need to have an existing data in the citizen database before getting their swab test added.

\section{Functionality and Connections}

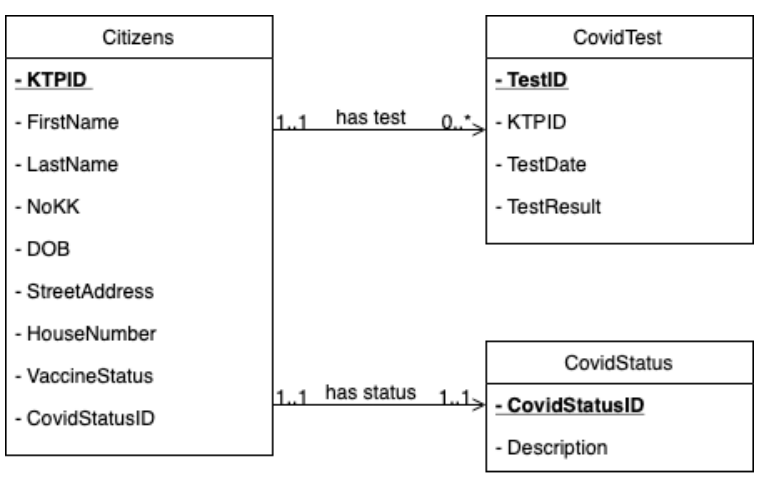

Picture 5. Entity Relationship Diagram of the Database

Whenever a new swab test result is added into the database, the system will also update the citizen's details with their latest result. For example, if Person A was previously negative, and a swab test today resulted in a positive, when adding the swab, the rest, Person A's COVID-19 status on the citizen table will be changed to positive. In addition, no swab test data can be added to a person that do not have a citizen data. 


\section{CONCLUSIONS}

With the drastically increasing cases of COVID-19, it is important to stay informed about the situation, and be able to keep track of the data to ensure that no additional person will be infected by the Coronavirus. Therefore, the website was developed to keep people of Kelurahan Gunung well-informed, and stay vigilant with this matter, which parallelly helps the government officials and medical staff of the subdistrict to keep track of the people within the area. As of now, the website can keep track of the citizens living in Kelurahan Gunung, and the swab tests that are done within the area. However, there are plans to add features to add in vaccination data, and ways to track the first and second dose, and the vaccine type. With the increased number of vaccines being available, it is also important to keep track of who is and who is not vaccinated in the subdistrict. The development of the website should help Kelurahan Gunung fight against COVID-19 and try to keep the subdistrict as informed as possible to avoid further spread and outbreak.

\section{REFERENCES}

Chande, A., Lee, S., Harris, M. et al. Real-time, interactive website for US-county-level COVID-19 event risk assessment. Nat Hum Behav 4, 1313-1319 (2020).

Cucinotta D, Vanelli M. WHO Declares COVID-19 a Pandemic.ActaBiomed.2020Mar19;91(1):157-160. doi: 10.23750/abm.v91u1.9397. PMID: 32191675; PMCID: PMC7569573.
COVID Live Update (2021). COVID-19 CORONAVIRUS PANDEMIC. Retrieved from https://www.worldometers.info/coronavirus/

COVID19.go.id (2021). Peta Pesebaran. Retrieved from https://covid19.go.id/peta-sebaran

Demi KTP Elektronik, Petugas Kelurahan Gunung Kebayoran Baru Sambangi Rumah Warga Saban Sabtu (2018, February 1), Tribun Jakarta, Retrieved from: https://jakarta.tribunnews.com

Hamzah, F. B., Lau, C., Nazri, H., Ligot, D. V., Lee, G., Tan, C. L., ... \& Chung, M. H. (2020). CoronaTracker: worldwide COVID-19 outbreak data analysis and prediction. Bull World Health Organ, 1(32).

Peta Pesebaran Positif COVID-19 (2021). Peta Pesebaran Kasus COVID-19 di Jakarta Hari Ini. Retrieved from https://corona.jakarta.go.id/id/peta-persebaran

Shrotri, M., Swinnen, T., Kampmann, B., \& Parker, E. P. (2021). An interactive website tracking COVID-19 vaccine development. The Lancet Global Health, 9(5), e590-e592. 